Abstract AB1276 Table 1. Incidents rates of diabetes mellitus in patients with JIA compared to healthy population and asthma patients

\begin{tabular}{|c|c|c|c|c|c|c|c|c|c|}
\hline & \multicolumn{3}{|c|}{ Healthy } & \multicolumn{3}{|c|}{ Asthma } & \multicolumn{3}{|c|}{ JIA } \\
\hline & Cases & $\begin{array}{l}\text { Person- } \\
\text { years }\end{array}$ & $\begin{array}{c}\mathrm{IR} \\
(95 \% \mathrm{Cl})\end{array}$ & Cases & $\begin{array}{l}\text { Person- } \\
\text { years }\end{array}$ & $\begin{array}{c}\text { IR } \\
(95 \% \mathrm{Cl})\end{array}$ & Cases & $\begin{array}{l}\text { Person- } \\
\text { years }\end{array}$ & $\begin{array}{c}\text { IR } \\
(95 \% \mathrm{Cl})\end{array}$ \\
\hline Type 1 DM & 62 & 276,695 & $\begin{array}{c}0.22 \\
(0.17- \\
0.28)\end{array}$ & 68 & 237,919 & $\begin{array}{c}0.29 \\
(0.23- \\
0.37)\end{array}$ & 18 & 39,943 & $\begin{array}{c}0.45 \\
(0.28- \\
0.71)\end{array}$ \\
\hline Type 2 DM & 134 & 276,573 & $\begin{array}{c}0.48 \\
(0.41- \\
0.57)\end{array}$ & 138 & 237,781 & $\begin{array}{c}0.58 \\
(0.49- \\
0.69)\end{array}$ & 27 & 39,930 & $\begin{array}{c}0.68 \\
(0.47- \\
0.99)\end{array}$ \\
\hline $\begin{array}{l}\text { Composite } \\
\text { DM }\end{array}$ & 147 & 276,540 & $\begin{array}{r}0.53 \\
(0.45- \\
0.62)\end{array}$ & 150 & 237,755 & $\begin{array}{c}0.63 \\
(0.54- \\
0.74)\end{array}$ & 34 & 39,907 & $\begin{array}{c}0.85 \\
(0.61- \\
1.19)\end{array}$ \\
\hline
\end{tabular}

Results: There were 2142 hip and knee arthroplasty performed, including 1118 operations on patients with RA and 1024 operations on patients with $\mathrm{OA}$. The number of local complications after total hip replacement was $155(7.24 \%)$ : 96 (8.59\%) of them were patients with RA and 59 $(5.76 \%)$ patients with $\mathrm{OA}$.

There were 1177 hip arthroplasty performed, including 467 operations on patients with RA and 710 operations on patients with OA. The number of local complications after total hip replacement was $85 \quad(7.22 \%): 48$ $(10.28 \%)$ of them were patients with RA and $37(5.21 \%)$ patients with OA. There were 965 knee arthroplasty performed, including 651 operations with RA patients and 314 operations in patients with OA were performed. The number of local complications after total knee replacement was 70 $(7,25 \%): 48(7.37 \%)$ of them were patients with RA and $22(7.00 \%)$ patients with $\mathrm{OA}$.

We revealed a significantly greater number of complications in patients with RA $(p<0.005)$.

Conclusion: Local complications after hip and knee arthroplasty with RA patients $(8.59 \%)$ more than in OA patients $(5.76 \%)$ in 1.5 times. It shows us that the operative treatment of patients with RA requires a special approach and more gentle management of patients with RA in co-operation with rheumatologist and careful treatment of the bone with surrounding tissues during the surgery.

Disclosure of Interests: None declared

DOI: 10.1136/annrheumdis-2019-eular.7013

\section{AB1276 THE RISK OF DIABETES MELLITUS IN PATIENTS WITH JUVENILE IDIOPATHIC ARTHRITIS: A COHORT STUDY}

Hemin Lee ${ }^{1}$, Yinzhu Jin ${ }^{1}$, Jun Liu ${ }^{1}$, Ezra Cohen ${ }^{2}$, Sarah Chen ${ }^{3}$, Seoyoung Kim ${ }^{1,3}$. ${ }^{1}$ Brigham and Women's Hospital, Division of Pharmacoepidemiology and

Pharmacoeconomics, Department of Medicine, Boston, United States of America;

${ }^{2}$ Boston Children's Hospital, Department of Rheumatology, Boston, United States

of America; ${ }^{3}$ Brigham and Women's Hospital, Division of Rheumatology,

Immunology and Allergy, Department of Medicine, Boston, United States of

America

Background: Few studies have suggested higher prevalence of type 1 diabetes mellitus (DM) in juvenile idiopathic arthritis (JIA). To date, the risk of type 1 or $2 \mathrm{DM}$ among patients with JIA patients has not been fully understood.

Objectives: To examine the incidence rate (IR) of DM in JIA patients compared to patients with asthma and healthy children.

Methods: We conducted a cohort study using a U.S. claims data from Truven MarketScan (2005-2016). We identified individuals between age 6 and 18 with $\geq 2$ diagnoses of JIA with International Classification of Diseases (ICD)-9 and 10 diagnostic codes followed by one dispensing of JIA-treatment medication. For comparison, we selected 1) children with asthma and 2) healthy individuals. Each JIA patient was matched by age, sex and index date to 5 asthma patients and 5 healthy children. The primary outcome was DM, identified with 1 ICD diagnostic code followed by one dispensing of an antidiabetic drug. We assessed type 1 DM and type 2 DM separately, and composite endpoint of type 1 or 2 DM. IR and hazard ratio (HR) of DM in JIA patients versus patients with asthma and healthy subjects was calculated along with stratification by age (6 to 12 versus 13 to 18 ).

Results: After 1:5 matching, there were 74,385 healthy children, 74,385 asthma patients, and 14,877 JIA patients. The mean age in all cohorts was 13.9 years and $66.9 \%$ were female. During a mean follow up of 3.72 years, the composite IR of DM in the JIA group was 0.85 per 1,000 person-years (95\% Confidence Interval [Cl], 0.61-1.19) compared to $0.63(0.54-0.74)$ per 1,000 person-years in the asthma population and $0.53(0.45-0.62)$ per 1,000 person-years in the healthy population (Table 1). The multivariable adjusted $\operatorname{HR}(95 \% \mathrm{Cl})$ associated with $\mathrm{DM}$ in JIA was $1.27(0.77-2.07)$ compared to the asthma group and $1.47(0.90-2.42)$ compared to the healthy population (Table 2). Age-stratified analyses also showed numerically increased risk of DM in JIA patients.

Conclusion: In our cohort of 163,647 children with 14,877 JIA patients, JIA was associated with a numerically higher, albeit not statistically significant, risk of type 1 or $2 \mathrm{DM}$ compared to asthma patients or healthy children.

\section{REFERENCES}

[1] Schenck S, et al. Comorbidity of Type 1 Diabetes Mellitus in Patients with Juvenile Idiopathic Arthritis. The Journal of pediatrics. Jan 2018;192:196203.

$\dagger$ The study cohorts were age-, sex-, and index date-matched. IR is per 1,000 person-years

Abstract AB1276 Table 2. Hazard ratio of diabetes mellitus in patients with JIA compared to healthy population and asthma patients

\begin{tabular}{lcccc}
\hline & \multicolumn{2}{c}{ JIA vs Asthma } & \multicolumn{2}{c}{ JIA vs Healthy Children } \\
\hline & Unadjusted HR & Multivariable HR & Unadjusted HR & Multivariable HR \\
& $(95 \% \mathrm{Cl})$ & $(95 \% \mathrm{Cl})$ & $(95 \% \mathrm{Cl})$ & $(95 \% \mathrm{Cl})$ \\
Type 1 DM & 1.54 & 1.51 & 1.93 & 1.62 \\
& $(0.91-2.58)$ & $(0.76-3.03)$ & $(1.14-3.27)$ & $(0.80-3.25)$ \\
Type 2 DM & 1.20 & 1.10 & 1.41 & 1.30 \\
& $(0.79-1.81)$ & $(0.64-1.89)$ & $(0.93-2.14)$ & $(0.74-2.26)$ \\
Composite & 1.37 & 1.27 & 1.59 & 1.47 \\
DM & $(0.94-1.98)$ & $(0.77-2.07)$ & $(1.09-2.31)$ & $(0.90-2.42)$ \\
\hline
\end{tabular}

$\dagger$ The full model includs age, demographics, comorbidities, medications, and health care utilization factors

Acknowledgement: This study was supported by an investigator-initiated research grant from Bristol-Myer-Squibb.

Disclosure of Interests: Hemin Lee: None declared, Yinzhu Jin: None declared, Jun Liu: None declared, Ezra Cohen: None declared, Sarah Chen: None declared, Seoyoung Kim Grant/research support from: Pfizer, Bristol-Myers Squibb, Roche/Genentech and AbbVie.

DOI: 10.1136/annrheumdis-2019-eular.1819

\section{AB1277 PREVALENCE OF THE DIFFERENT ANTI- CARBAMYLATED PROTEIN ANTIBODIES ISOFORMS IN FIRST-DEGREE RELATIVES OF PATIENTS WITH RHEUMATOID ARTHRITIS IN A LATIN POPULATION}

Ana Sofía Leal Bramasco, Cesar Vidal Solis, Luis Eduardo Ramírez Monterrubio, Lorena Pérez Barbosa, David Vega Morales, Jorge Antonio Esquivel Valerio, Mario Alberto Garza Elizondo, Dionicio Ángel Galarza Delgado, Karina Itzel González Márquez. Hospital Universitario Dr José Eleuterio Gonzalez, Reumatología e Inmunología Clínica, Monterrey, Mexico

Background: Rheumatoid arthritis (RA) affects approximately $1.5 \%$ of the population worldwide and $0.5-3.3 \%$ of the Mexican population ${ }^{1}$. Anti-carbamylated proteins (anti-CarP) antibodies are identified in RA patients with a prevalence up to $44 \%{ }^{2}$, early arthritis, first-degree relatives (FDR) of patients with RA with a prevalence of $18 \%$, and healthy controls with a prevalence of $4.7 \%$. There is no evidence regarding the prevalence of the three different isoforms of anti-CarP antibodies worldwide.

Objectives: Establish the prevalence of the different isoforms of anti-CarP antibodies ( $\lg A, \lg M, \lg G)$ in $F D R s$ of patients with RA.

Methods: It is an observational descriptive cohort. Subjects underwent a complete physical examination, made by a certificated rheumatologist which included clinical and serological measurements. The serological measurements included anti-citrullinated peptides antibodies (ACPA), RF, and anti-CarP detected by ELISA using carbamylated fetal calf serum, according to Shin $\mathrm{J}$ et al with some modifications. The cut-offs for the 